\title{
Effects on the development of Spodoptera frugiperda feeding on diets spiked with Solanum sisymbriifolium extracts
}

Ignacio Migues $^{1+}$ (D) Neiva Montero de Barros $^{2}\left(\mathbb{D}\right.$, Vânia Rech ${ }^{2}$, Carmelo Dutra ${ }^{1}$, Alejandro Ruiz Díaz ${ }^{1}$, Juaci Vitória

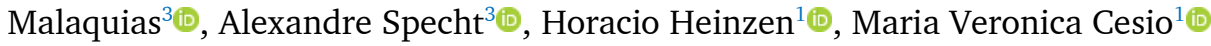

1. Universidad de la República, Chemistry Institute, Pharmacognosy \& Natural Products, 2124 General Flores Av, Montevideo, Uruguay.

2. University of Caxias do Sul, Biotechnology Institute, Pest Control Laboratory, 1130 Francisco Getúlio Vargas St, Caxias do Sul, Rio Grande do Sul, Brazil.

3. Embrapa Cerrados, BR-020, km 18, Planaltina, Brasília - DF, Brasil.

+Corresponding author: Ignacio Migues, Phone: +598 2924-4068 email address: imigues@fq.edu.uy

\section{ARTICLE INFO}

Article history:

Received: July 25, 2019

Accepted: March 05, 2020

Published: April 1, 2020
Keywords:

1. fall armyworm

2. pest management

3. Solanum sisymbriifolium

4. biopesticides

5. sugar esters

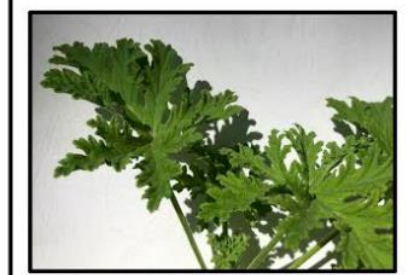

Solanum sisymbriifolium

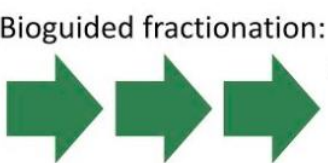

survival and

development

effect over

S. frugiperda
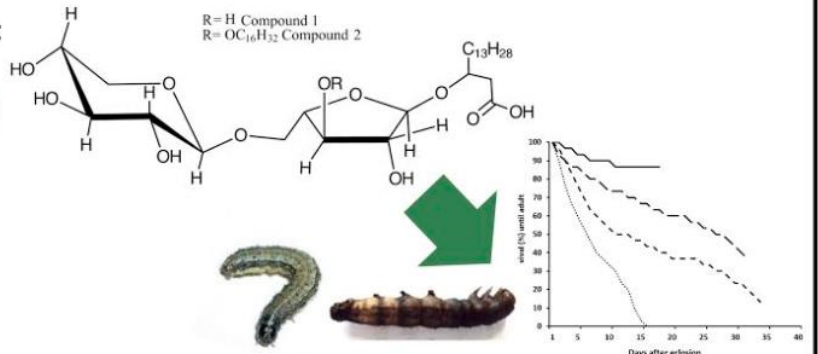

ABSTRACT: Aiming to evaluate the effects of Solanum sisymbriifolium extracts on the development of Spodoptera frugiperda, a leaf dichloromethane extract was obtained and subjected to further purification following a bioguided methodology. The structure of the two main compounds isolated from S. sisymbriifolium Type IV glandular trichomes have been completely elucidated by a combination of chemical and spectroscopic methods. They are glycosides of 3-(R)-hydroxypalmitic acid and xylo ( $\beta-1-5)$ furanoarabinoside (Compound 1) and its 3-O-palmitoyl derivative (Compound 2). These compounds greatly influenced the survival and the development of S. frugiperda, when compared to an in vitro test control. The extracts delayed the development, decreased survival and promote abnormalities in the immatures (larvae and pupae). They also showed increasing toxicity towards $S$. frugiperda in the purification following a bioguided fractionation. The pure compounds had the most deleterious activity, increasing the larval and pupal toxicity (100\% mortality for Compound 2 at $2.50 \mathrm{mg} \mathrm{mL}^{-1}$ and $90 \%$ mortality for Compound 1 at $\left.1.00 \mathrm{mg} \mathrm{mL}^{-1}\right)$.

\section{Introduction}

\subsection{Solanum sisymbriifolium}

Solanum sisymbriifolium L. is a spiky, perennial and invasive weed, native from the Rio de la Plata basin. By visual inspection, the shrub is almost free of herbivore insects. Interactions between plants and insects within an ecosystem are essentially physicochemical ${ }^{1}$. The insect is either attracted or repelled towards a plant, following complex and specific physicochemical cues ${ }^{2} S$. sisymbriifolium's epicuticle shows a very complex structural morphology, dense arrays of different kinds of hairs cover the abaxial and adaxial sides of the leaf ${ }^{3}$. Glandular trichomes are another physical/chemical defense line that contain preconceived compounds that are released when 
the trichome is broken by some external stimulus. Because of this, the content of the trichomes is extracted with the epicuticular wax of the leaf ${ }^{4}$. However, it is possible to differentiate the origin of these compounds analyzing only the content of the glandular trichomes ${ }^{5}$. Epicuticular wax is removed from the surface of the leaves using non-polar solvents for a short period (normally $30 \mathrm{~s}$ ) in order not to remove internal lipids ${ }^{6,7}$. Trichome compounds can be separated from waxes by freezing out an acetone solution of the epicuticular extract. Trichome chemistry is diverse and many bioactive metabolites have been isolated from these storage structures, such as terpenes, alkaloids, phenols, flavonoids and sugar esters. In most cases, the shape and morphology of trichomes is characteristic of the type of compounds they contain $^{8,9}$. Visual inspection of S. sisymbriifolium leaf under the microscope, allowed the identification of type IV trichomes, which are the predominating ones over the abaxial side of the leaf. These trichomes are known for producing many bioactive compounds especially acyl sugars, compounds which play a key role within some of the chemically mediated interactions of many Solanaceae plants and their environment. Among the different bioactivities reported such as antihypertensive, analgesic, anti-diarrheic, antioxidant and antibacterial ${ }^{10-14}$, some anti-insect properties of the compounds have been described in literature ${ }^{15}$.

\subsection{Spodoptera frugiperda}

Spodoptera frugiperda is an endemic Lepidoptera all over the American continent that in the last decade has reached Africa, Europe and India and probably in some years will invade all the countries around the world ${ }^{16}$. It is considered as a key-pest and its larvae attack more than 350 plants belonging to 76 plant families, mainly Poaceae including cultivated plants as corn, rice, soybeans and cotton ${ }^{17,18}$. Rapid development and fertility allow $S$. frugiperda to have a high number of offspring $\left(2.086 \times 10^{29}\right.$ individuals/female/ year) ${ }^{19,20}$. Only in Brazil it is responsible for losses of over $\$ 40$ million per year ${ }^{21}$. As these larvae attack a wide variety of plants is difficult to develop an effective control strategy ${ }^{22}$. Caterpillars are usually controlled with chemicals that can be harmful to the applicators and the environment and in several cases, remain in soil and plants causing biological unbalance and generating the appearance of resistant populations ${ }^{23}$. Moreover, these chemicals affect negatively the food safety.

In larval phase, insects choose appropriate food to obtain nutrients that favor their growing and development into sexually competitive adults. In field conditions $S$. frugiperda complete development cycle has a 30-day duration, with six instars, a larval phase of 14 days and pupae size of 14-18 $\mathrm{mm}$ with a duration period of 8-9 days when growing at $25^{\circ} \mathrm{C}$ but when reared on artificial diets, the larval phase is shorter as well as the pupal phase $^{19}$.

In the present communication the chemical composition of the exudates from $S$. sisymbriifolium type IV trichomes and the bioactivity of the extracts isolated compounds towards Spodopera frugiperda is reported.

\section{Experimental}

\subsection{General}

GC was performed using an HP 6890 chromatograph - Mass Selective Detector 5973, Split Mode, $\mathrm{T}_{\text {Inj: }}: 290{ }^{\circ} \mathrm{C}, \mathrm{T}_{\text {interphase }}: 280^{\circ} \mathrm{C}, \mathrm{T}_{\text {source: }}$ : $230{ }^{\circ} \mathrm{C}, \mathrm{T}_{\text {quadrupole: }}: 140^{\circ} \mathrm{C}$. Constant flow, Capillary HP-5 column, Carrier: Helium. Temperature program: $\mathrm{T}_{\mathrm{i}}: 60^{\circ} \mathrm{C}, 5 \mathrm{~min}, 5{ }^{\circ} \mathrm{C} \mathrm{min}^{-1}$ until $\mathrm{T}_{\mathrm{f}}: 270$ ${ }^{\circ} \mathrm{C}, 5 \mathrm{~min}$. The compound identification was done by comparison with the NIST-05 library.

NMR experiments $\left({ }^{1} \mathrm{H}\right.$ and ${ }^{13} \mathrm{C}$, mono and bi dimensional) were performed using a Bruker Avance 400 and $100 \mathrm{MHz}$ respectively, using $\mathrm{CDCl}_{3}$ as solvent and TMS as internal reference, using the standard sequences for the bidimensional experiments.

The MALDI-TOF/MS spectra were obtained using a Voyager DE-PRO instrument (Applied Biosystems), with 4-cyanohydroxycinnamic acid as matrix.

The absolute configuration of $3(R)$ hydroxypalmitic acid was performed using a Krüss P8000 polarimeter (Krüss Optronic) equipped with software V3.0 using $5 \mathrm{~cm}$ cells.

All reagents were Sigma Aldrich analytical grade. The thin layer plates were Polygram Sil/UV254 $0.25 \mathrm{~mm}$ Layer (Macherey-Nagel), and the mobile phase used was $\mathrm{CHCl}_{3} / \mathrm{MeOH}$ (9:1). All extracts were concentrated under reduced pressure with temperatures below $60{ }^{\circ} \mathrm{C}$.

The dyeing reagents used were:

1) $5 \%$ de $\mathrm{CuSO}_{4}$ in $10 \%$ aqueous solution of $\mathrm{H}_{3} \mathrm{PO}_{4}$. 
2) Diphenylamine:Aniline:Phosphoric Acetone.

\subsection{Plant Material}

S. sisymbriifolium samples were collected in Montevideo, Uruguay (-34.888761, -56.185015), they were identified and kept at the Jose Arechavaleta Herbarium in the Faculty of Chemistry, UdelaR, Uruguay (Voucher number 3520).

\subsection{Extracts}

The extraction method was performed following Rech-Cainelli et al. $2015^{24}$, where $300 \mathrm{~g}$ of fresh leaves were immersed portion wise in 1000 $\mathrm{mL}$ of dichloromethane for $30 \mathrm{~s}$ in order to extract only epicuticular waxes compounds. The dichloromethane solutions were evaporated under reduced pressure to dryness (Dichloromethane extract). To yield the enriched fraction of sugar esters, $1 \mathrm{~g}$ of the previous extract was dissolved in acetone $(100 \mathrm{~mL})$ and the solution was cooled to $-20{ }^{\circ} \mathrm{C}$ and kept overnight at this temperature. The resulting precipitate was discarded and the acetone extract was evaporated under reduced pressure to dryness (Dichlormethane/acetone extract).

\subsection{Bioguided fractionation}

The phytochemical study was done following a bio-guided fractionation, using the enriched fraction of sugar esters and the composition of the different fractions was evaluated by TLC. Open column chromatography was performed with the dichloromethane/acetone extract in order to isolate the two major sugar esters. $1 \mathrm{~g}$ of the extract was used into a $50 \mathrm{~g}$ of silica Gel (Baker 60-200 Mesh) column, and a total of $250(10 \mathrm{~mL})$ fractions were collected using an increasing polarity solvent mixture until the isolation of compounds 1 and 2.

The identification of Compounds 1 and 2 fatty acids was done following the methodology proposed by Heinzen et al. $(1985)^{25}$.

\subsection{Absolute configuration of $3(R)$ - hydroxypalmitic acid}

The methyl ester of the glycoside $2(10 \mathrm{mg})$ was kept under stirring overnight at RT in $3 \mathrm{~mL}$ of $10 \%$ $\mathrm{HCl}$ in $\mathrm{MeOH}$. A mixture of dichloromethane: water 1:1 $(10 \mathrm{~mL})$ was added and the phases partitioned through centrifugation. The polarized light deviation of the dichloromethane solution was measured and the $\{\alpha\}$ D calculated.

\subsection{Evaluation of $S$. sisymbriifolium extracts bioactivity over $S$. frugiperda}

The larvae were reared following the methodology described by Montezano et al. $(2019)^{19}$. They were fed with artificial $\operatorname{diet}^{26}$ and maintained under controlled conditions $\left(25 \pm 2{ }^{\circ} \mathrm{C}\right.$, $70 \pm 10 \% \mathrm{RH}$ and photoperiod of $14 \mathrm{~h}$ ) at the Biotechnology Institute, Universidade de Caxias do Sul, Brazil.

The extracts were diluted in Tween-80 (5\%) and mixed with the diet until total homogenization.

The bioassays were performed with $1 \mathrm{~cm}^{3}$ diet blocks spiked with the test solution at $0.25,1.00$ and $2.50 \mathrm{mg} \mathrm{mL}^{-1}$ levels and a control group, in 50 $\mathrm{mL}$ plastic glasses. Neonate larvae were placed individually (each one was considered a repetition) in the plastic glasses for the assays.

Two bioassays were performed: the first one used 700 newborn larvae (100 replicates for each condition) to evaluate the effect of the three levels of extract 1 (E1 at $0.25, \mathrm{E} 1$ at 1.00 and E1 at 2.50 $\mathrm{mg} \mathrm{mL} \mathrm{m}^{-1}$ ) and the three levels of extract 2 (E2 at 0.25 , E2 at 1.00 and $\mathrm{E} 2$ at $2.50 \mathrm{mg} \mathrm{mL}^{-1}$ ), besides the control group.

The second bioassay used 210 newborn larvae (30 replicates for each condition) to evaluate the effect of the three levels of Compound 1 ( $\mathrm{C} 10.25$, C1 1.00 and $\left.\mathrm{C} 12.50 \mathrm{mg} \mathrm{mL}^{-1}\right)$ and three levels of Compound 2 (C2 $0.25, \mathrm{C} 21.00$ and $\mathrm{C} 22.50 \mathrm{mg}$ $\mathrm{mL}^{-1}$ ), besides the control group.

All the replicates were observed individually until the moth emergence (adult), registering the daily survival and adult malformations.

\subsection{Statistical analysis}

The average survival time curves (larvae to adult) were elaborated using Kaplan-Meier estimator and comparisons between survival curves were made using Log Rank test with $\mathrm{R}$ 
version 3.5.127. The curves were compared between each extract and each compound.

\section{Results and Discussion}

The addition of $S$. sisymbriifolium dichloromethane extract (E1) and dichloromethane/acetone extract (sugar esters enriched extract) E2 at $0.25, \mathrm{E} 2$ at 1.00 and E2 at $2.50 \mathrm{mg} \mathrm{mL}^{-1}$ concentrations to the diet affected the development of $S$. frugiperda, effect that can be verified by the survival curves (Fig. 1).

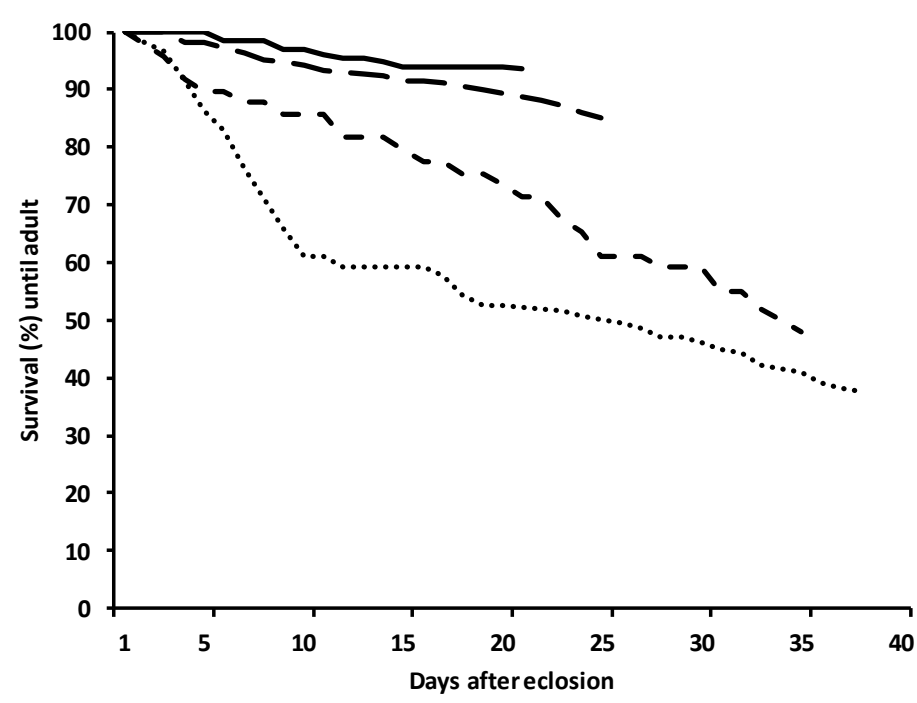

(a)

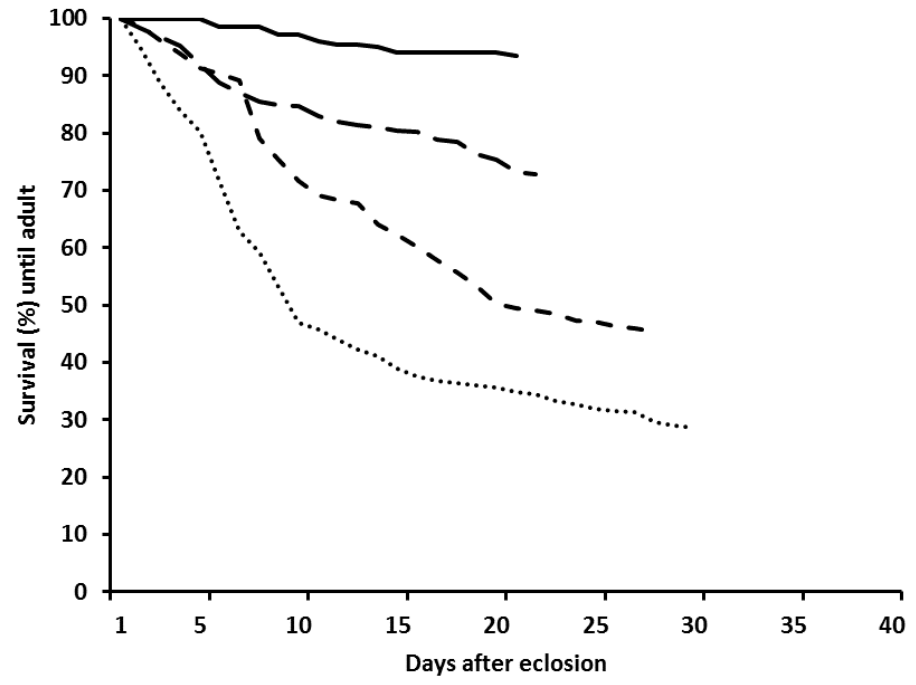

(b)

Figure 1. Survival curves of immature Spodoptera frugiperda (larvae, prepupae, and pupae) from larvae reared on artificial diet spiked with dichloromethane extract E1 (a) and E2 (b). Continuous line control (without extract); dashed line (large dashes) extract at $0.25 \mathrm{mg} \mathrm{mL}^{-1}$; dashed line (short dashes) extract at $1.00 \mathrm{mg} \mathrm{mL}^{-1}$ and dotted line extract at $2.50 \mathrm{mg} \mathrm{mL}^{-1}$. Note that the curves stopped at the percentage of adults emerged (Log Rank test, $\chi 2=110-118, \mathrm{df}=3, \mathrm{p}$ $<0.001)$ see Table 2.

The larvae fed on artificial diet with dichloromethane extract (E1) showed a survival percentage of $85 \%\left(0.25 \mathrm{mg} \mathrm{mL}^{-1}\right), 48 \%(1.00 \mathrm{mg}$ $\left.\mathrm{mL}^{-1}\right)$ and $38 \%\left(2.50 \mathrm{mg} \mathrm{mL}^{-1}\right)$ (Fig. 1a), in a dose dependent mortality effect (Fig. 1).

The larvae fed on artificial diet with dichloromethane / acetone extract (E2) showed greater effects on survival of $S$. frugiperda with ratios of $72 \%\left(0.25 \mathrm{mg} \mathrm{mL}^{-1}\right), 45 \%\left(1.00 \mathrm{mg} \mathrm{mL}^{-1}\right)$ and $29 \%$ (2.50 $\left.\mathrm{mg} \mathrm{mL}^{-1}\right)$ (Fig. 1b), also with a dose dependent mortality effect (Fig. 1). Because E2 showed a greater toxic overall effect and this extract was further fractionated.

It was assumed that the decreased insect survival could be related to compounds from type IV glandular trichomes which were isolated with the leaf wax and subsequently purified in the dichloromethane/acetone extract. These types of compounds are acyl sugars, with known bioactivity against insects and fungi ${ }^{5,28-30}$.
Two major acyl sugar derivatives were isolated after silica gel column chromatography, visualized in TLC plates with the Sugar dyeing reagent $\left(R_{f}=\right.$ 0.3 and 0.25 ).

The structure of both isolated compounds was totally elucidated by NMR and GC as described in experimental section. In previous works, Cesio et al. $(2006)^{7}$ reported a rough description of the structure of acyl sugar methyl esters, not the naturally occurring compound. The fatty acid composition was determined by GC/MS of the methyl esters derivatives. The whole structure was proposed using the GC alditol analysis combined with the HMBC NMR experiment. The structure of the occurring natural product, the non-esterified compounds, was deduced after a thoroughly study of the MALDI-TOF/MS spectrum, and additional bidimensional NMR experiments.

Basic hydrolysis of Compound 2 yielded only palmitic acid. On the other hand, its exhaustive acid hydrolysis yielded two pentose residues, and a 
levorotatory $\beta$-hydroxy fatty acid, identified as 3$(R)$ hydroxypalmitic acid after GC-MS analysis and the comparison to literature values of the optical properties of 3-hydroxy acids. The pentoses were identified through alditol analysis as arabinose and xylose in a 1:1 relationship. These findings suggested a compound having the structure of a glycoside of an arabinoxylan linked to the hydroxypalmitic acid and esterified with palmitic acid, Further confirmation was obtained through MALDI-TOF/MS analysis of the methyl ester of the glycoside, which detected a neat $\mathrm{m} / \mathrm{z}=797.5392[\mathrm{M}+\mathrm{Na}]^{+}$peak, and smaller one at $\mathrm{m} / \mathrm{z}=775.5574[\mathrm{M}+\mathrm{H}]^{+}$. The final structure determination of Compound 1 was achieved through NMR experiments. A complex pattern of ${ }^{13} \mathrm{C}$ and ${ }^{1} \mathrm{H}$ NMR signals of a disaccharide spectra was obtained for Compound 2. A detailed analysis of ${ }^{13} \mathrm{C}$ spectra of Compound 1 yielded two carboxyl carbons at $\delta=177 \mathrm{ppm}$ and a signal at $\delta=107.8 \mathrm{ppm}$, characteristic of an arabinofuranoside conformation. The other anomeric carbon was detected at $\delta=104.2 \mathrm{ppm}$, consistent with a carbohydrate in the pyranose conformation. The signals corresponding to $9 \mathrm{C}-\mathrm{O}$ resonances appeared between $\delta=60$ and $\delta=80 \mathrm{ppm}$. Finally, two signals at $\delta=14$ and $\delta=17 \mathrm{ppm}$ that correspond to the methyl groups of the fatty acid chains that substituted the arabinofuranose carbohydrate framework were also detected. The ${ }^{1} \mathrm{H}$ NMR spectra of Compound 1 showed a region of methylenic protons between $\delta=1$ and $\delta=2 \mathrm{ppm}$, a multiplet at $\delta=2.8 \mathrm{ppm}$ which are consistent with the alpha protons of a $\beta$-hydroxyacid and another multiplet centered at $\delta=2.2 \mathrm{ppm}$ corresponding to the protons alfa to the acyl residue attached to the dissacharide. The sugar protons appeared between $\delta=3.2$ and $\delta=5.2 \mathrm{ppm}$. Bidimensional NMR experiments allowed the full characterization of the molecule. The HSQC-TOCSY experiment showed four spin systems. The two carbohydrate residues were clearly differentiated. The two anomeric carbons were detected at $\delta=107.8 \mathrm{ppm}$ and $\delta=104.2$ $\mathrm{ppm}$ in the ${ }^{13} \mathrm{C}$ NMR spectrum, the monosaccharide units with anomeric protons at $\delta=5.2$ and $4.45 \mathrm{ppm}(\mathrm{J}=5.4)$ corresponded to two pentoses with their methylene carbons at $\delta=68.7$ and $\delta=65.8 \mathrm{ppm}$, respectively, and were identified as $\alpha$-L-furanoarabinose and $\beta$-D-xylose. The third spin system belonged to the fatty acid residue attached to the disaccharide. Whereas the fourth spin system corresponded to a $\beta$-hydroxy carboxylic acid system $\delta=4.11,2.8 \mathrm{ppm}$ aligned through the ${ }^{13} \mathrm{C}$ signal at $(\delta=74.1)$. COSY ${ }^{1} \mathrm{H}-{ }^{1} \mathrm{H}$ connectivity allowed the unambiguous assignment of all protons and therefore the identification of the structure of each monosaccharide (Tab. 1). The HMBC experiment gave the intramolecular connectivity that allowed the final structure elucidation of Compound 1. Cross peaks between araf C-1 $(\delta=107.8) \quad \mathrm{H}-3$ of hydroxypalmitic $(\delta=4.11)$ and $\mathrm{C}-3(\delta=74.1)$ of hydroxypalmitic and the anomeric signal of araf (5.15); between C-1 $(\delta=177)$ of palmitic acid and araf $\mathrm{H}-3 \quad(\delta=4.11)$ showed the substitution of the arabinose residue. A third group of cross peaks were detected between the C-5 of $\operatorname{araf}(\delta=68.7)$, and $\mathrm{H}-1 \mathrm{xyl}(\delta=4.20)$; the geminal protons $\mathrm{H}-5 \operatorname{araf}(\delta=4.07 ; 3.80)$ and the C$1(\delta=104.2)$ of the terminal xylose unit. They were indicative of a glycosidic linkage between the anomeric carbon of the xylose residue and the C-5 araf- geminal protons, showing the xylo- $\beta-1-5$ araf- structure of Compound $1^{31}$. Based on the above discussed data, we propose that the Compound 2 structure is the 3-araf-palmitate of. [3- $(R)$-hydroxypalmitic acid] (araf-1) $\rightarrow$ xylo ( $\beta 1$ 5) furanoarabinoside, (Fig. 2).

The structure of Compound 2 was deduced comparing the spectral data and chemical properties of Compound 1. The acid hydrolysis of Compound 2 gave the same carbohydrate and hydroxy acid residues as for Compound 1 but no palmitic acid was detected after basic hydrolysis. MALDI-TOF/MS spectrum showed a peak at $\mathrm{m} / \mathrm{z}=559.3095[\mathrm{M}+\mathrm{Na}]^{+}$which is consistent to a disaccharide of xylose and arabinofuranose with a $3-(R)$ hydroxypalmitic acid. ${ }^{13} \mathrm{C}$ NMR spectrum showed only the signal at $\delta=14 \mathrm{ppm}$ from one methyl group and only one signal at $\delta=176 \mathrm{ppm}$ was detected. The signal at $\delta=4.2 \mathrm{ppm}$ had shifted to $\delta=3.6 \mathrm{ppm}$, indicating that Compound 2 is the unesterified glycoside of Compound 1. Bidimensional NMR experiments (HSQCTOCSY, ${ }^{1} \mathrm{H}^{-}{ }^{1} \mathrm{H}$ COSY, HMBC) were consistent and confirmed Compound 1 as $[3-(R)-$ hydroxypalmitic acid] (araf-1) and xylo ( $\beta 1-5)$ arabinofuranoside (Fig. 2). 
Table 1. ${ }^{1} \mathrm{H}$ and ${ }^{13} \mathrm{C}$ relevant assignments of the glycosidic template of Compound 1 and 2 using $1 \mathrm{D}$ and 2D $\mathrm{NMR}$ experiments with a $100 \mathrm{MHz}$ field in $\mathrm{CDCl}_{3}$.

\begin{tabular}{|c|c|c|c|c|}
\hline \multirow{2}{*}{ Carbon } & \multicolumn{3}{|c|}{ Compound 1 } & arabinose $(f)$ \\
\cline { 2 - 5 } & $\mathbf{H}$ & $\mathbf{C}$ & $\mathbf{H}$ & $\mathbf{C}$ \\
\hline $\mathbf{1}$ & $4.45(\mathrm{~J}=2.7 \mathrm{~Hz})$ & 104.2 & $5.06(\mathrm{~J}=5.4 \mathrm{~Hz})$ & 107.8 \\
\hline $\mathbf{2}$ & $3.45(\mathrm{~J}=3.5,2.7 \mathrm{~Hz})$ & 76.8 & $3.93(\mathrm{~J}=7.1,5.4 \mathrm{~Hz})$ & 76.2 \\
\hline $\mathbf{3}$ & $3.35(\mathrm{~J}=3.5 \mathrm{~Hz})$ & 73.7 & $3.99(\mathrm{~J}=7.1,4.4 \mathrm{~Hz})$ & 76.4 \\
\hline $\mathbf{4}$ & $3.62(\mathrm{~J}=3.5,2.9,2.7 \mathrm{~Hz})$ & 69.9 & $3.98(\mathrm{~J}=4.7,4.4 \mathrm{~Hz})$ & 83.2 \\
\hline $\mathbf{5}$ & $3.23(\mathrm{~J}=13.3,2.9 \mathrm{~Hz})$ & 65.8 & $4.02(\mathrm{~J}=4.7 \mathrm{~Hz})$ & 68.7 \\
\hline
\end{tabular}

\begin{tabular}{|c|c|c|c|c|}
\hline \multicolumn{3}{|c|}{ Compound 2 } \\
\hline \multirow{2}{*}{ Carbon } & xylose & arabinose $(\mathbf{f})$ \\
\cline { 2 - 5 } & $\mathbf{H}$ & 104.2 & $5.15(\mathrm{~J}=5.4 \mathrm{~Hz})$ & 107.8 \\
\hline $\mathbf{2}$ & $4.45(\mathrm{~J}=2.7 \mathrm{~Hz})$ & 76.8 & $4.05(\mathrm{~J}=7.1,5.4 \mathrm{~Hz})$ & 80.4 \\
\hline $\mathbf{3}$ & $3.45(\mathrm{~J}=3.5,2.7 \mathrm{~Hz})$ & 73.7 & $4.90(\mathrm{~J}=7.1,4.4 \mathrm{~Hz})$ & 80.2 \\
\hline $\mathbf{4}$ & $3.35(\mathrm{~J}=3.5 \mathrm{~Hz})$ & 69.9 & $4.15(\mathrm{~J}=4.4,4.3 \mathrm{~Hz})$ & 83.1 \\
\hline $\mathbf{5}$ & $3.62(\mathrm{~J}=3.5,2.9,2.7 \mathrm{~Hz})$ & & $4.07(\mathrm{~J}=4.3 \mathrm{~Hz})$ & 6 \\
\hline
\end{tabular}

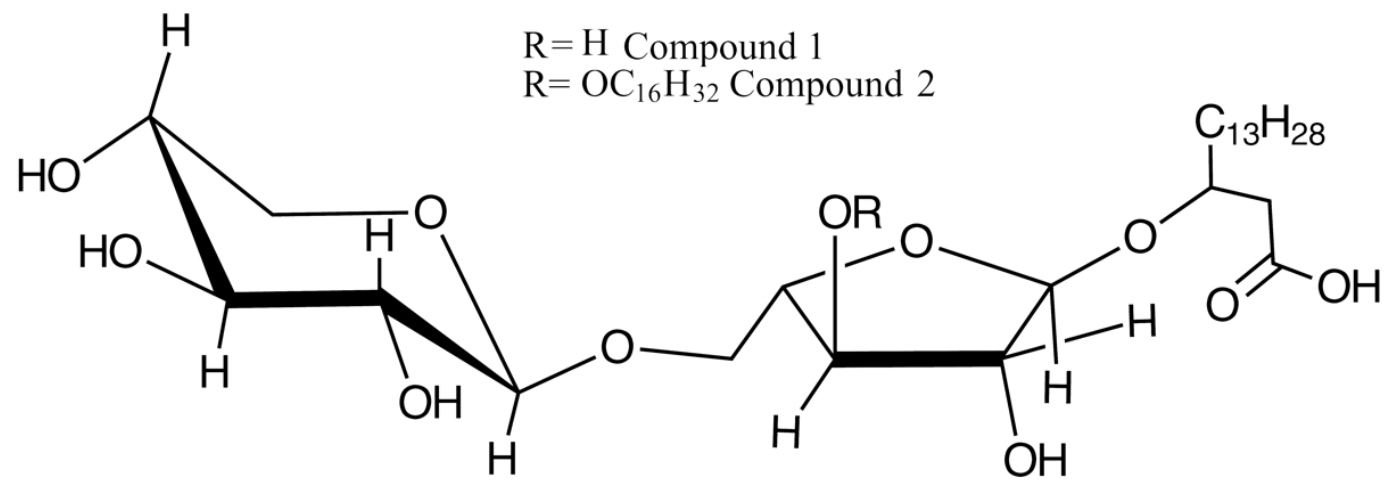

Figure 2. Molecular structures of Compounds 1 and 2.

Summarizing we postulate that the structures of the acyl sugars from S. sisymbriifolium are:

Compound 1: xylo $(\beta-1-5)$ furanoarabinoside $(\alpha-1-3) 3-(R)$-hydroxypalmitic acid $\quad \mathrm{C}_{26} \mathrm{H}_{48} \mathrm{O}_{11}$. MALDI-TOF/MS $[\mathrm{M}+\mathrm{Na}]^{+}=559.3095$. Calculated 559.3094, and for Compound 2: 3-O araf- Palmitic acid ester of xylo ( $\beta-1-5)$ furanoarabinoside $\quad(\alpha-1-33-(R)$-hydroxypalmitic acid $\mathrm{C}_{42} \mathrm{H}_{78} \mathrm{O}_{12}[\mathrm{M}+\mathrm{Na}]^{+}=797.5392$ Calculated 797.5391.

Furthermore, the biological activity of the two isolated compounds was studied in bioassays conducted on artificial diet spiked with them. The results are shown in Fig. 3. Tables 2, 3 and 4 show the results of the Log Rank test with the $c^{2}$ values for the different situations at different confidence levels. This test is the preferred one to compare if 
the survival of populations when exposed to different stressors are independent events or not. All the compounds and extracts caused significantly higher mortality than the control during the bioassays. Furthermore, the toxicity of the pure compounds was also significantly higher than that caused by the crude extracts (see Tab. 4).

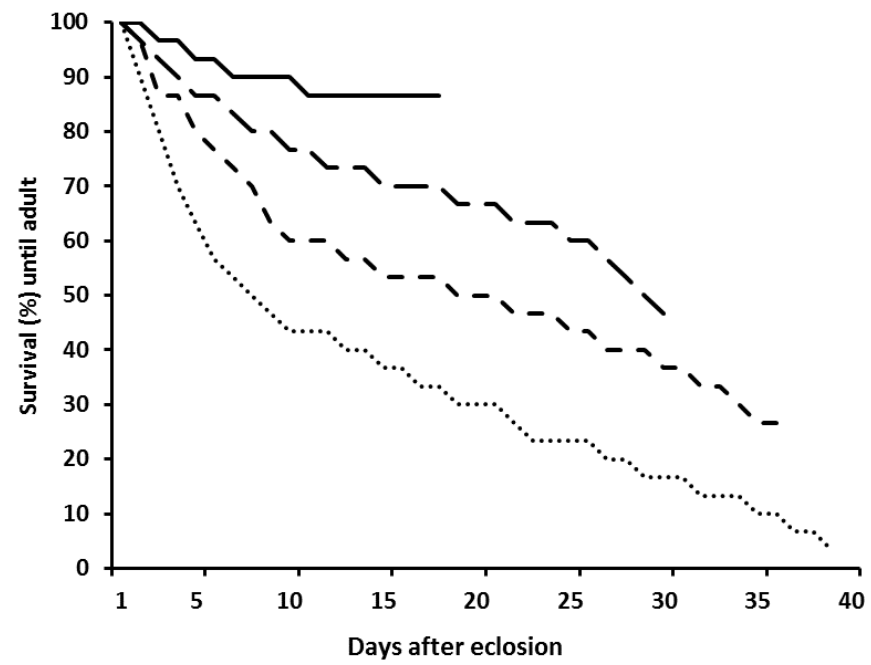

(a)

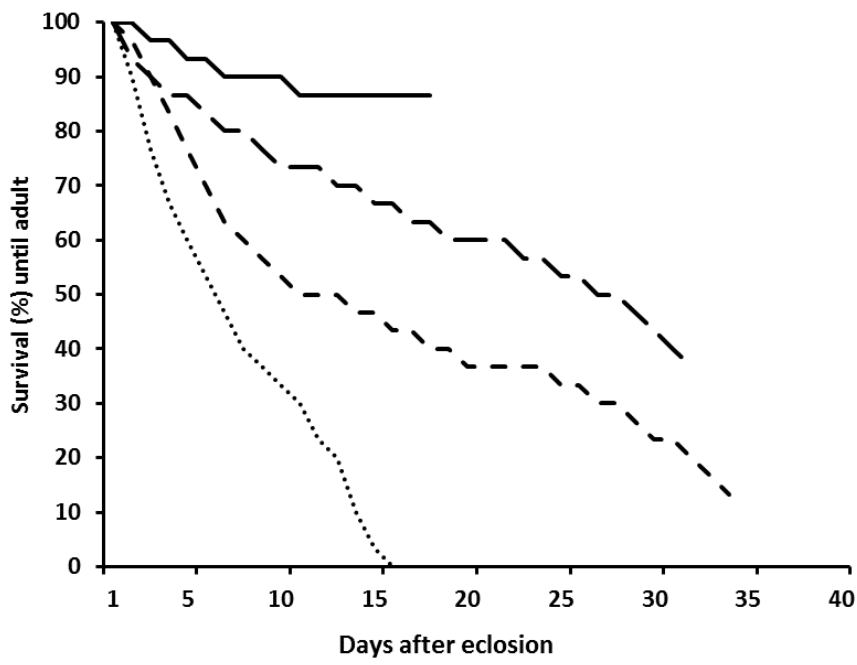

(b)

Figure 3. Survival curves of immature Spodoptera frugiperda (larvae, prepupae, and pupae) from larvae reared on artificial diet spiked with Compounds 1 (a) and $\mathbf{2}$ (b). Continuous line control (without extract); dashed line (large dashes) $0.25 \mathrm{mg} \mathrm{mL}^{-1}$; dashed line (short dashes) $1.00 \mathrm{mg} \mathrm{mL}^{-1}$ and dotted line $2.50 \mathrm{mg} \mathrm{mL}^{-1}$. Note that the curves stopped at the percentage of adults emerged (Log Rank test, $\chi 2=38-51$, df $=3, \mathrm{p}<0.001$ ) see Tab. 3.

Table 2. Chi-square and p-values from Log Rank test for comparison between survival curves of Spodoptera frugiperda (larvae, prepupae, and pupae) from larvae reared on artificial diet spiked with dichloromethane extract E1 and E2.

\begin{tabular}{|l|c|c|c|c|c|}
\hline & DF & $\begin{array}{c}\chi^{2} \\
\text { Extract 1 }\end{array}$ & $\mathbf{p}$ & $\begin{array}{c}\chi^{\mathbf{2}} \\
\text { Extract 2 }\end{array}$ & $\mathbf{p}$ \\
\hline General comparison among all curves & 3 & 110.1 & $<0.001$ & 118.0 & $<0.001$ \\
\hline Control $\times 0.25 \mathrm{mg} \mathrm{mL}^{-1}$ & 1 & 5.5 & $=0.020$ & 18.9 & $<0.001$ \\
\hline Control $\times 1.00 \mathrm{mg} \mathrm{mL}^{-1}$ & 1 & 54.2 & $<0.001$ & 60.8 & $<0.001$ \\
\hline Control $\times 2.50 \mathrm{mg} \mathrm{mL}^{-1}$ & 1 & 75.9 & $<0.001$ & 98.4 & $<0.001$ \\
\hline & DF & $\chi^{2}$ & $\mathbf{p}$ & $\chi^{\mathbf{2}}$ & $\mathbf{p}$ \\
\hline $0.25 \mathrm{mg} \mathrm{mL}^{-1} \times 1.00 \mathrm{mg} \mathrm{mL}^{-1}$ & 1 & 29.4 & $<0.001$ & 16.1 & $<0.001$ \\
\hline $0.25 \mathrm{mg} \mathrm{mL}^{-1} \times 2.50 \mathrm{mg} \mathrm{mL}^{-1}$ & 1 & 49.1 & $<0.001$ & 43.3 & $<0.001$ \\
\hline & DF & $\chi^{2}$ & $\mathbf{p}$ & $\chi^{2}$ & $\mathbf{p}$ \\
\hline $1.00 \mathrm{mg} \mathrm{mL}^{-1} \times 2.50 \mathrm{mg} \mathrm{mL}^{-1}$ & 1 & 3.8 & $=0.050$ & 7.7 & $=0.006$ \\
\hline
\end{tabular}


Table 3. Chi-square and p-values from Log Rank test for comparison between survival curves of Spodoptera frugiperda (larvae, prepupae, and pupae) from larvae reared on artificial diet spiked with Compounds 1 and 2.

\begin{tabular}{|l|c|c|c|c|c|}
\hline & DF & $\begin{array}{c}\chi^{\mathbf{2}} \\
\text { Compound 1 }\end{array}$ & $\mathbf{p}$ & $\begin{array}{c}\chi^{\mathbf{2}} \\
\text { Compound 2 }\end{array}$ & $\mathbf{p}$ \\
\hline General comparison among all curves & 3 & 38.2 & $<0.001$ & 58.9 & $<0.001$ \\
\hline Control $\times 0.25 \mathrm{mg} \mathrm{mL}^{-1}$ & 1 & 9.3 & $=0.002$ & 12.7 & $<0.001$ \\
\hline Control $\times 1.00 \mathrm{mg} \mathrm{mL}^{-1}$ & 1 & 20.9 & $<0.001$ & 26.1 & $<0.001$ \\
\hline Control $\times 2.50 \mathrm{mg} \mathrm{mL}^{-1}$ & 1 & 36.7 & $<0.001$ & 48.4 & $<0.001$ \\
\hline & DF & $\chi^{2}$ & $\mathbf{p}$ & $\chi^{\mathbf{2}}$ & $\mathbf{p}$ \\
\hline $0.25 \mathrm{mg} \mathrm{mL}^{-1} \times 1.00 \mathrm{mg} \mathrm{mL}^{-1}$ & 1 & 2.7 & $=0.100$ & 2.7 & $=0.100$ \\
\hline $0.25 \mathrm{mg} \mathrm{mL}^{-1} \times 2.50 \mathrm{mg} \mathrm{mL}^{-1}$ & 1 & 10.6 & $=0.001$ & 21.2 & $<0.001$ \\
\hline & DF & $\chi^{2}$ & $\mathbf{p}$ & $\chi^{2}$ & $\mathbf{p}$ \\
\hline $1.00 \mathrm{mg} \mathrm{mL}^{-1} \times 2.50 \mathrm{mg} \mathrm{mL}^{-1}$ & 1 & 2.4 & $=0.100$ & 9.1 & $=0.003$ \\
\hline
\end{tabular}

Table 4. Chi-square and p-values from Log Rank test for comparison between survival curves of Spodoptera frugiperda (larvae, prepupae, and pupae) from larvae reared on artificial diet spiked with extracts 1 and 2 and Compounds 1 and 2 at each concentration.

\begin{tabular}{|c|c|c|c|}
\hline & DF & $\underset{\text { Extract } 1 \times \text { Extract } 2}{\chi^{2}}$ & $\mathbf{p}$ \\
\hline $0.25 \mathrm{mg} \mathrm{mL}^{-1}$ & 1 & 4.7 & $=0.030$ \\
\hline $1.00 \mathrm{mg} \mathrm{mL}^{-1}$ & 1 & 0.8 & $<0.400$ \\
\hline \multirow[t]{2}{*}{$2.50 \mathrm{mg} \mathrm{mL}^{-1}$} & 1 & 2.1 & $<0.100$ \\
\hline & DF & Compound $1 \times$ Compound 2 & $\mathbf{p}$ \\
\hline $0.25 \mathrm{mg} \mathrm{mL}^{-1}$ & 1 & 0.4 & $=0.500$ \\
\hline $1.00 \mathrm{mg} \mathrm{mL}^{-1}$ & 1 & 0.5 & $=0.500$ \\
\hline $2.50 \mathrm{mg} \mathrm{mL}^{-1}$ & 1 & 4.7 & $=0.030$ \\
\hline
\end{tabular}

It was observed that compounds 1 and 2 at concentrations of $0.25,1.00$ and $2.50 \mathrm{mg} \mathrm{mL}^{-1}$ affected the development of $S$. frugiperda. The observed mortality was concentration-dependent for compound 1 and 2 (Fig. 3). After 40 days of evaluation, Compound 1 did not reach $100 \%$ mortality with the higher evaluated concentration. But Compound 2 achieved $100 \%$ mortality evaluated in the same condition after 15 days of experiment.

Moreover, the overall number of insects reaching the adult phase were $46.29 \%(0.25 \mathrm{mg}$ $\left.\mathrm{mL}^{-1}\right), 15.27 \%\left(1.00 \mathrm{mg} \mathrm{mL}^{-1}\right)$ and $3.46 \%(2.50 \mathrm{mg}$ $\mathrm{mL}^{-1}$ ) for Compound 1 (Fig. 3).

When Compound 2 was evaluated, the survival observed percentages were $36.72 \% \quad(0.25 \mathrm{mg}$ $\left.\mathrm{mL}^{-1}\right), 11.11 \%(1.00 \mathrm{mg} / \mathrm{mL})$ and zero $(2.50 \mathrm{mg}$ $\mathrm{mL}^{-1}$ ) (Fig. 3).

$S$. frugiperda feeding behavior as a polyphagous insect requires large amounts of food for their development to reach the adult stage.
There is no evidence of sugar esters acute toxicity to insects, and the intake may be a prerequisite to detect the deleterious effects of these compounds ${ }^{32}$.

As observed in other studies evaluating effects of plant extracts on S. frugiperda development ${ }^{33-35}$, in all treatments, beyond mortality, were observed abnormalities in immatures that which qualitatively demonstrate the effects of extracts and compounds on the development of S. frugiperda.

The isolated compounds, evaluated at the same concentration levels, were more toxic than the crude extracts assayed and caused noticeable abnormalities in the metamorphosis phase. The abnormalities that resulted in the interruption of the metamorphosis process have similar characteristics as those already described for lefenuron, which acts as an insect's growth regulator ${ }^{36}$. 


\section{Conclusions}

The two evaluated extracts increase the immature mortality of $S$. frugiperda. This effect could be related to the individual acyl sugars tested.

The dichloromethane / acetone extract (sugar ester enriched extract) E2, highly affected the larval survival rather than the pupal.

The response was dose dependent and the major compounds (1 and 2) from this extract were isolated and their structures elucidated.

When the pure compounds were added to the diet, a significant effect was observed in the metamorphosis phase, as many of the exposed caterpillars failed to accomplish the transformation to reach the pupal stage. See Fig. 4a, 4b, 4c. With Compound 1, the rates of mortality of the insects failing to survive the larval to pupal phase transition were $27 \%\left(1.00 \mathrm{mg} \mathrm{mL}^{-1}\right)$ and $53 \%(2.50$ $\mathrm{mg} \mathrm{mL}^{-1}$ ). The mortality of the insects that could not complete their metamorphosis was $17 \%(0.25$ $\left.\mathrm{mg} \mathrm{mL} \mathrm{m}^{-1}\right)$ and $50 \%\left(\mathrm{mg} \mathrm{mL}^{-1}\right)$, both compounds showed important effects over the larval stage. See Fig. 4d and 4e.
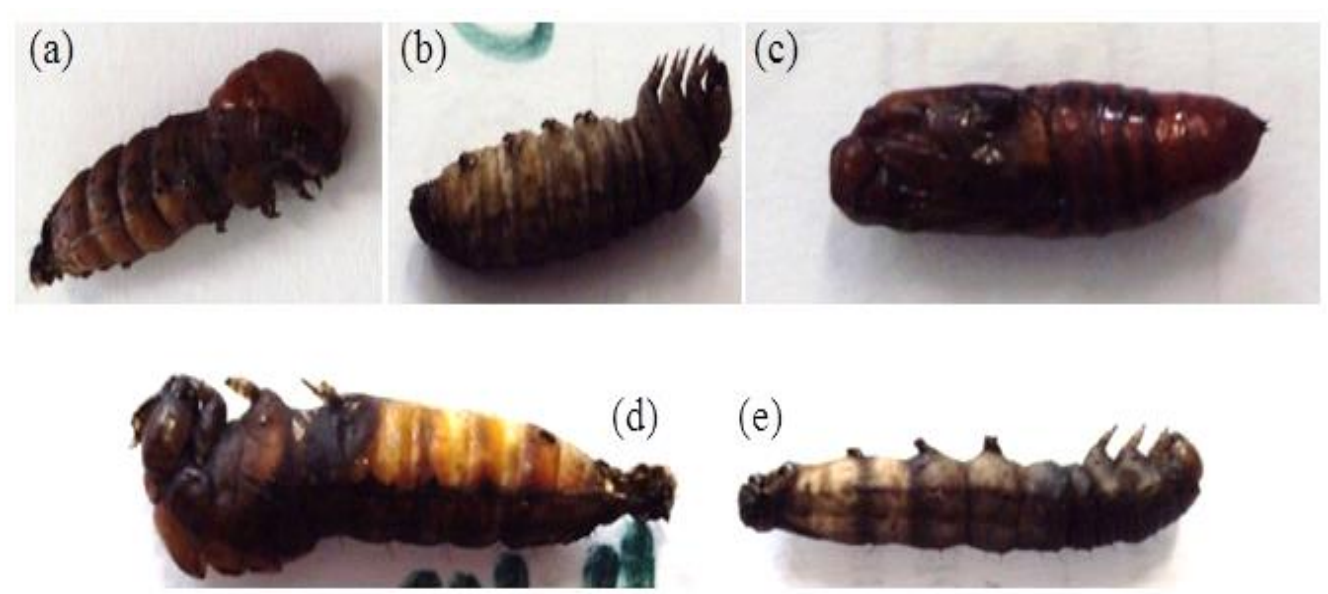

Figure 4. Abnormalities found in S. frugiperda larval stage when fed with artificial diet spiked with Compound 2 (a, b \& c) and with Compound 1 (d \& e).

Compounds 1 and 2 showed high toxicity levels over the $S$. frugiperda larval phase with almost $100 \%$ mortality for Compound 1 at $2.50 \mathrm{mg} \mathrm{mL}^{-1}$ and $90 \%$ mortality for Compound 2 at $1.00 \mathrm{mg}$ $\mathrm{mL}^{-1}$.

These results show that the acyl sugars isolated from $S$. sisymbriifolium trichomes are a new class of bioactive compounds that affect the development of the fall armyworm S. frugiperda. Due to their simple chemical structures, they could be interesting lead compounds for the synthesis of new agents for pest control working as biopesticides contributing with the sustainability of different ecosystems.

\section{Acknowledgments}

The authors would like to acknowledge CAPES-UdelaR and PEDECIBA QUIMICA for supporting this research and the academic exchanges between Brazil and Uruguay.

\section{References}

[1] Burkart, A., Bacigalupo, N. M., Flora ilustrada de Entre Rios (Argentina): Dicotiledóneas metaclamideas (gamopétalas), A: Primulales a plantaginales, In: Colección Científica del Instituto Nacional de Tecnología Agropecuaria, Buenos Aires, 1978.

[2] Seithe, A., Hair types as taxonomic characters in Solanum, In: The Biology and Taxonomy of the Solanaceae, Hawkes, J. G., Lester, R. N., Skelding, A. D., (Eds.), Linnean Society of London, London, 1979.

[3] Liedl, B. E., Lawson, D. M., White, K. K., Shapiro, J. A., Cohen, D. E., Carson, W. G., Trumble, J. T., Mutschler, M. A., Acylsugars of wild tomato Lycopersicon pennellii alters settling and reduces oviposition of Bemisia argentifolii (Homoptera: Al eyrodidae), Journal of Economic Entomology 88 (3) (1995) 742-748. https://doi.org/10.1093/jee/88.3.742.

[4] Wollenweber, E., Dörr, M., Rivera, D., Roitman, J. N., Externally accumulated flavonoids in three Mediterranean Onion species, Zeitschrift für Naturforschung C: A Journal of Biosciences 58 (11-12) 
(2003) 771-775. https://doi.org/10.1515/znc-2003-111202.

[5] Dutra, C., Cesio, M. V., Moyna, P., Heinzen, H., Acyl sucroses from Salpichroa origanifolia, Natural Product Communications 3 (4) (2008) 539-542. https://doi.org/10.1177/1934578X0800300413.

[6] García, S., Heinzen, H., Hubbuch, C., Martínez, R., Devries, X. de, Moyna, P., Triterpene methyl ethers from Palmae epicuticular waxes, Phytochemistry 39 (6) (1995) 1381-1382. https://doi.org/10.1016/00319422(95)00173-5.

[7] Cesio, M. V., Dutra, C., Moyna, P., Heinzen, H., Morphological and chemical diversity in the Type IV glandular trichomes of Solananeae (S. sisymbriifolium and N. glauca) as germplasm resources for agricultural and food uses, Electronic Journal of Biotechnology 9 (3) (2006) 281-285. https://doi.org/10.2225/vol9-issue3fulltext-4.

[8] Smith, C. M., Use of plant resistance in insect pest management systems, In: Plant Resistance to Insects, Wiley, New York, 1989.

[9] Smith, C. M., What is plant resistance to insects? In: Plant Resistance to Insects, Wiley, New York, 1989.

[10] More, G. K., A review of the ethnopharmacology, phytochemistry and pharmacological relevance of the South African weed Solanum sisymbriifolium Lam. (Solanaceae), Environment, Development and Sustainability $21 \quad$ (1) (2019) 37-50. https://doi.org/10.1007/s10668-017-0042-6.

[11] lbarrola, D. A., Hellión-lbarrola, M. C., Montalbetti, Y., Heinichen, O., Alvarenga, N., Figueredo, A., Ferro, E. A., Isolation of hypotensive compounds from Solanum sisymbriifolium Lam, Journal

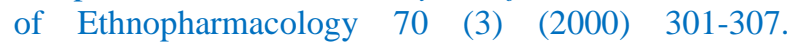
https://doi.org/10.1016/S0378-8741(00)00191-4.

[12] Apu, A. S., Bhuyan, S. H., Matin, M., Hossain, F., Khatun, F., Jamaluddin, A. T., Analgesic, neuropharmacological, anti-diarrheal, and cytotoxic activities of the extract of Solanum sisymbriifolium (Lam.) leaves, Avicenna Journal of Phytomedicine 3 (4) (2013) 302-31. https://doi.org/10.22038/ajp.2013.384.

[13] Pasdaran, A., Pasdaran, A., Mamedov, N., Antibacterial and Antioxidant Activities of the Volatile Composition of the Flower and Fruit of Solanum sisymbriifolium (Litchi Tomato), Pharmaceutical $\begin{array}{llll}\text { Sciences } & 23 & \text { (1) 66-71. }\end{array}$ https://doi.org/10.15171/PS.2017.10.
[14] Moehninsi, D., Navarre, D. A., Brown, C. R., Phytonutrient content of Solanum sisymbriifolium Lam. berries, Journal of Food Composition and Analysis 44 (2015) 73-79. https://doi.org/10.1016/j.jfca.2015.07.004.

[15] Puterka, G. J., Severson, R. F., Activity of sugar esters isolated from leaf trichomes of Nicotiana gossei to pear psylla (Homoptera: Psyllidae), Journal of Economic Entomology 88 (3) (1995) 615-619. https://doi.org/10.1093/jee/88.3.615.

[16] CABI, Invasive Species Compendium, Spodoptera frugiperda (Fall armyworm), 2019. https://www.cabi.org/isc/datasheet/29810\#toreferences.

[17] Capinera, J. L., Encyclopedia of entomology, Springer, Dordrecht, 2nd ed., 2008. https://doi.org/10.1007/978-1-4020-6359-6.

[18] Montezano, D. G., Specht, A., Sosa-Gómez, D. R., Roque-Specht, V. F., Sousa-Silva, J. C., Paula-Moraes, S. V. de, Peterson, J. A., Hunt, T. E., Host Plants of Spodoptera frugiperda (Lepidoptera: Noctuidae) in the Americas, African Entomology 26 (2) (2018) 286-300. https://doi.org/10.4001/003.026.0286.

[19] Montezano, D. G., Specht, A., Sosa-Gómez, D. R., Roque-Specht, V. F., Malaquias, J. V., Paula-Moraes, S. V. de, Peterson, J. A., Hunt, T. E., Developmental parameters of Spodoptera frugiperda (Lepidoptera: Noctuidae) immature stages under controlled and standardized conditions, Journal of Agricultural Science 11 (8) (2019) 76-89. https://doi.org/10.5539/jas.v11n8p76.

[20] Montezano, D. G., Specht, A., Sosa-Gómez, D. R., Roque-Specht, V. F., Malaquias, J. V., Paula-Moraes, S. V. de, Peterson, J. A., Hunt, T. E., Biotic Potential and Reproductive Parameters of Spodoptera frugiperda (J. E. Smith, 1797) (Lepidoptera: Noctuidae), Journal of Agricultural Science 11 (13) (2019)240-252. https://doi.org/10.5539/jas.v11n13p240.

[21] Cruz, I., Figueiredo, M. L. C., Oliveira, A. C., Vasconcelos, C. A., Damage of Spodoptera frugiperda (Smith) in different maize genotypes cultivated in soil under three levels of aluminium saturation, International Journal of Pest Management 45 (4) (1999)293-296. https://doi.org/10.1080/096708799227707.

[22] Barros, E. M., Torres, J. B., Bueno, A. F., Oviposition, development, and reproduction of Spodoptera frugiperda (J.E. Smith) (Lepidoptera: Noctuidae) fed on different hosts of economic importance, Neotropical Entomology 39 (6) (2010) 9961001. https://doi.org/10.1590/S1519. $566 \times 2010000600023$. 
[23] Whalon, M. E., Mota-Sanchez, D., Hollingorth, R. M., Global Pesticide Resistance in Arthropods, Blackwell Publishing Ltd., London, 2008. https://doi.org/10.1079/9781845933531.0000.

[24] Rech-Cainelli, V., Barros, N. M. de, Garcia-Gianni, S., Sbeghen-Loss, A. C., Heinzen, H., Díaz, A. R., Migues, I., Specht, A., Cesio, M. V., Antifeedant and repellent effects of neotropical Solanum extracts on drywood termites (Cryptotermes brevis, Isoptera: Kalotermitidae), Sociobiology An International Journal on Social Insects 62 (1) (2015) 82-87. https://doi.org/10.13102/sociobiology.v62i1.82-87.

[25] Heinzen, H., Moyna, P., Grompone, A., Gas chromatography determination of fatty acid compositions, Journal of Chemical Education 62 (5) (1985) 449-450. https://doi.org/10.1021/ed062p449.

[26] Greene, G. L., Leppla, N. C., Dickerson, W. A., Velvet bean Caterpillar: a rearing procedure and artificial medium, Journal of Economic Entomology 69 (4) (1976) 487-488. https://doi.org/10.1093/jee/69.4.487.

[27] Efron, B., Logistic regression, survival analysis, and the Kaplan-Meier curve, Journal of the American Statistical Association 83 (402) (1988) 414-425. https://doi.org/10.2307/2288857.

[28] Neal Junior, J. W., Buta, J. G., Pittarelli, G. W., Lusby, W. R., Bentz, J.-A., Novel sucrose esters from Nicotiana gossei: Effective biorationals against selected horticultural insect pests, Journal of Economic

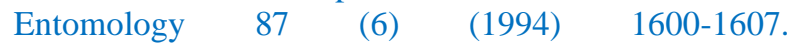
https://doi.org/10.1093/jee/87.6.1600.

[29] Buta, J. G., Lusby, W. R., Neal Junior, J. W., Waters, R. M., Pittarelli, G. W., Sucrose esters from Nicotiana gossei active against the greenhouse whitefly Trialeuroides vaporariorum, Phytochemistry 32 (4) (1993) 859-864. https://doi.org/10.1016/00319422(93)85220-L.

[30] Yencho, G. C., Renwick, J. A. A., Steffens, J. C., Tingey, W. M., Leaf surface extracts of Solanum berthaultii Hawkes deter Colorado potato beetle feeding, Journal of Chemical Ecology 20 (1994) 9911007. https://doi.org/10.1007/BF02059737.

[31] Agrawal, P. K., NMR spectroscopy in the structural elucidation of oligosaccharides anf glycosides, Phytochemistry $31 \quad$ (10) (1992) 3307-3330. https://doi.org/10.1016/0031-9422(92)83678-R.

[32] Neal, J. J., Tingey, W. M., Steffens, J. C., Sucrose esters of carboxylic acids in glandular trichomes of Solanum berthaultii deter settling and probing by green peach aphid, Journal of Chemical Ecology 16 (1990) 487-497. https://doi.org/10.1007/BF01021780.

[33] Roel, A. R., Dourado, D. M., Matias, R., Porto, K. R. A., Bednaski, A. V., Costa, R. B. da, The effect of sub-lethal doses of Azadirachta indica (Meliaceae) oil in the midgut of Spodoptera frugiperda (Lepidoptera, Noctuidae), Revista Brasileira de Entomologia 54 (3) (2010) 505-510. https://doi.org/10.1590/S008556262010000300024 .

[34] Sarria, A. L. F., Soares, M. S., Matos, A. P., Fernandes, J. B., Vieira, P. C., Silva, M. F. G. F. da, Effect of triterpenoids and limonoids isolated from Cabralea canjerana and Carapa guianensis (Meliaceae) against Spodoptera frugiperda (J.E. Smith), Zeitschrift für Naturforschung C: A Journal of Biosciences 66 (56) (2011) 245-250. https://doi.org/10.1515/znc-2011-5607.

[35] Magrini, F. E., Specht, A., Gaio, J., Girelli, C. P., Migues, I., Heinzen, H., Saldaña, J., Sartori, V. C., Cesio, V., Antifeedant activity and effects of fruits and seeds extracts of Cabralea canjerana canjerana (Vell.) Mart. (Meliaceae) on the immature stages of the fall armyworm Spodoptera frugiperda (JE Smith) (Lepidoptera: Noctuidae), Industrial Crops and Products $65 \quad$ (2015) 150-158. https://doi.org/10.1016/j.indcrop.2014.11.032.

[36] Cohen, E., Chitin synthesis and inhibition: a revisit, Pest Management Science 57 (10) (2001) 946-950. https://doi.org/10.1002/ps.363. 